Dept. of Animal Hygiene,

Faculty of Veterinary Medicine,

Assiut University, Assiut, Egypt.

\title{
WATER-BORNE CRYPTOSPORIDIUM PARVUM OOCYSTS CAUSING LIFE-THREATENING INFECTION OF BUFFALOES AND SHEEP IN EGYPT
}

(With 2 Tables and One Figure)

\author{
By
}

\section{S. KOTB; A. ABDEL-RADY* and M. TANAKA**}

* Dept. of Animal Medicine, Fac. of Vet. Med., Assiut University, Assiut, Egypt.

** Animal Physiology, National Agricultural Research Centre for Kyushu Okinawa Region, Kumamoto, Japan,

(Received at 4/10/2010)

حويصلات الكريبتوسبوريديم الملوثة للمياه تسبب العدوى المهدده لحياة الجاموس والأغنام في مصر لمر تهر

صابر قطب ، احد عبل الراضي ، ماسهيتو تاناكا

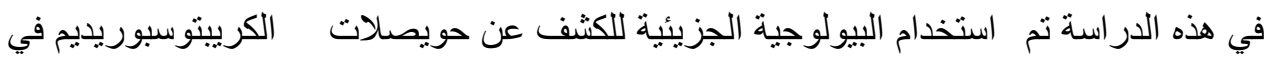

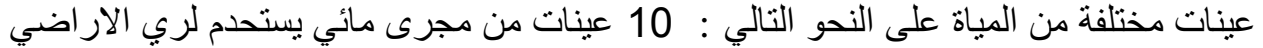

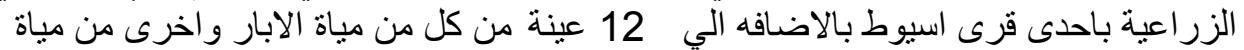

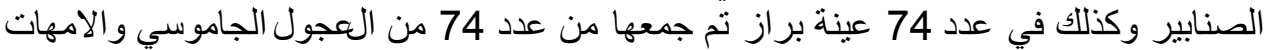

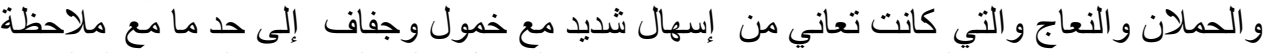

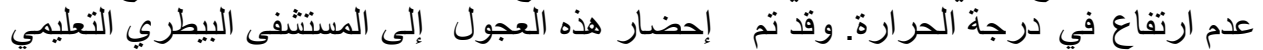

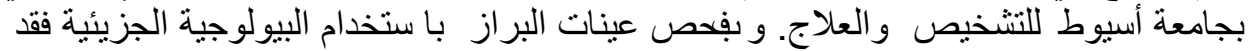

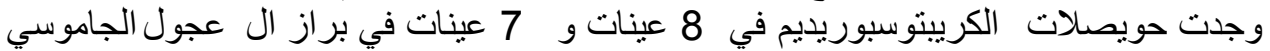

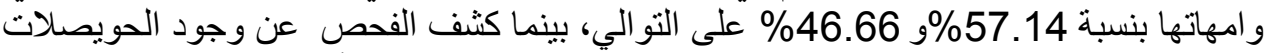

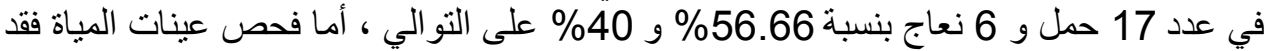

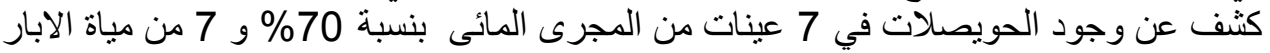

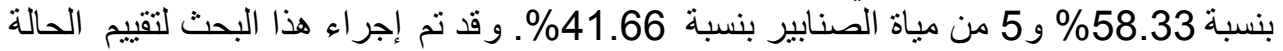

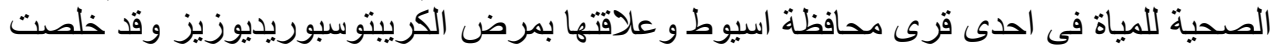



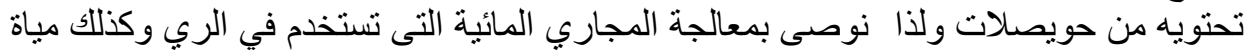

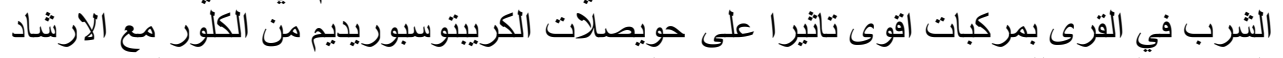

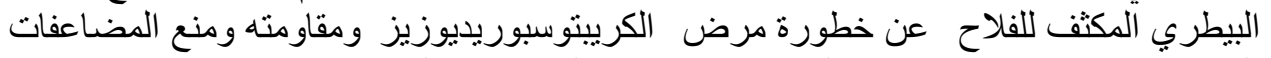
الثي قد تنتج عن الإصابة به في الحيو ان والانسان و الذي يؤدي إلى إلى خسارة اقتصادية كبيرة.

\section{SUMMARY}


This study was carried out in a village at Assiut Governorate, Egypt to detect the prevalence of Cryptosporidium parvum in different water samples that affecting the health condition of buffaloes and sheep. A total of 34 different types of water samples and 74 fecal samples from waterbuffaloes and sheep were tested for Cryptosporidium parvum oocysts using PCR techniques. Cryptosporidium parvum were detected in local surface water, dug-well and tap-water in percentage of $70 \%, 58.33 \% \& 41,66 \%$, respectively, with overall percentage of $55.88 \%$. Moreover, our study showed that the overall percentage of Cryptosporidium parvum among buffaloes and sheep in Assiut province, Egypt were 51.77\% and 51.11\%, respectively. Moreover, the results showed that the percentage of Cryptosporidium parvum oocysts in adult ewes and lambs were $40.00 \%$ and $56.66 \%$, respectively and adult female buffaloes and buffalo's calves were $46.66 \%$ and $57.14 \%$, respectively.

Key words: Cryptosporidium, water, buffaloes, sheep, fecal matter, PCR.

\section{INTRODUCTION}

In recent years, there has been a dramatic increase in the incidence of waterborne disease outbreaks caused by the Cryptosporidium oocysts. This parasite is increasingly recognized as important agents that causes enteric infection in man and many species of domestic animals (Chalmers et al., 2002). Cryptosporidium parasite is most common in young livestock and a high morbidity and mortality rates has been reported as enteropathogenic being associated with neonatal diarrhea in ruminants (Angus, 1990 and de-Graaf et al., 1999). Although the fecal-oral route is the main infection mode, this parasite is frequently transmitted via water (Casemore et al., 1997; Graczyk et al., 1997a and Rose, 1997), and is considered as the most important biological water contaminants in the United States (Rose et al., 1997). A nationwide recent survey in the United States reveled that $55 \%$ of surface water samples from 17 states were positive to Cryptosporidium spp., while only $17 \%$ of 36 drinking water samples was positive for Cryptosporidium oocysts (Rose et al., 1991). In addition, Rose (1997) reported that $77 \%$ of 107 samples from the western United States contained Cryptosporidium oocysts. In Japan, Hashimoto et al. (2002) detected the oocysts of Cryptosporidium in all of the 13 river water samples, while only $35 \%$ of filter water samples were positive for Cryptosporidium oocysts.

Outbreak in ruminants is frequently parasitized with Cryptosporidium species which cause diarrhea and impair gain of body 
weight. Cryptosporidium parvum in cattle is potential zoonotic pathogens for human and due to increase incidence of Cryptosporidiosis in cattle; it is important to through light on the role of water-buffaloes and sheep as the source of waterborne outbreaks of Cryptosporidiosis. Cryptosporidium infections have been considering causes of disease and production losses in calves, particularly the effects of subclinical and chronic infections (Olson et al., 2004).

There are many current methodology for diagnosis of cryptosporidiosis as using modified Ziehl-Neelsen (acid-fast) staining or immunofluoresce assay in water samples as well as in fecal matter but these methods is time consuming, labour intensive, and is subject to false positive results (LeChevallier et al., 2003). So, we use polymerase chain reaction (PCR) based method as has the potential to address many limitations of the current methods. PCR has many advantages include specificity, greater sensitivity and more rapidity (Kaucner and Stinear, 1998).

The objective of this study was to examine adult buffaloes, buffaloes- calves, ewes and lambs and some water sources in a village located in Assiut Governorate, Egypt, after many complains of diarrhea in the newly born buffaloes-calves that recorded in this village to determine the extent of Cryptosporidium infection using molecular technique.

\section{MATERIALS and METHODS}

\section{Animals:}

\subsection{Animals and data collection}

A total number of 14 buffalo-calves (1-3 month old age) and 30 lambs ( 3 week-2 month old age) as well as 15 of both adult buffaloes (from 5 to 8 years) and ewes (about 3 year old age) at a private small scale herds in Arab-Motear village at Assiut governorate, Egypt were selected with case history of suffering from acute or chronic diarrhea. A questionnaire was done about herd profiles management, general health history, presence of other animals. Some of these animals came to Veterinary teaching hospital, Assiut University for diagnosis and treatment from diarrhea with case history of grazing in the vicinity of local surface water streams used for irrigation of cultivated land. The animals were subjected for clinical examination including body temperature, mucous membranes and degree of dehydration.

\section{Water Samples and sampling preparation:}


10 water samples from different sites of small local water branch in Arab-Moteer village, derived from Ibrahimia canal (a branch of river Nile) and used for irrigation of cultivated lands, in addition to 12 water samples from dug-wells inside this village and 12 tap water samples were collected.

\subsection{Isolation of Cryptosporidium parvum DNA from water samples}

Water samples ranging in volume from 40 to 50 liter were filtered as described previously by Aldom and Chagla (1995) and the processed method for preparing water samples prior to PCR amplification as described to Kostrzynska et al. (1999). The pellets retained on filters were washed 3 to 4 times and suspended in $10 \mathrm{ml}$ of water. Aliquots $(1 \mathrm{ml})$ from each sample were mixed with $9 \mathrm{ml}$ of PBS-Tween and filtered through sterile 44-mm and then 20-mm nylon filter cloth, followed by centrifugation at $10000 \mathrm{~g}$ for $15 \mathrm{~min}$. Pellets were resuspended in $10 \mathrm{ml}$ PBS containing $0.1 \%(\mathrm{w} / \mathrm{v})$ bovine serum albumin (PBS- BSA) and oocysts were purified using an immuno-magnetic separation (IMS) procedure as the following description according to Lowery et al. (2000). Filtered water samples were resuspended in $10 \mathrm{ml}$ PBS-BSA, mixed with $100 \mu \mathrm{l}$ of coated beads and incubated for $1 \mathrm{~h}$ at $22^{\circ} \mathrm{C}$. The oocystsmagnetic particle complexes were separated from the suspension using a magnetic particle concentrator and washed with PBS. The antibodyoocysts complexes were disrupted by vigorous vortexing for $1 \mathrm{~min}$ and beads removed using magnetic separation. Cryptosporidium oocysts were concentrated by centrifugation at $14000 \mathrm{~g}$ for $15 \mathrm{~min}$. Pellets were resuspended in $50 \mu \mathrm{l}$ of water and DNA was released from oocysts by ten freeze-thaw cycles. Following centrifugation at $14000 \mathrm{~g}$ for $15 \mathrm{~min}$, supernatants were used as templates in PCR.

\section{Isolation of C. parvum DNA from fecal samples}

Fecal specimens were collected from the rectum of all selected animals and were prepared according to Johnson et al. (1995). Fecal samples stored in $2.5 \%$ potassium dichromate were washed several times (4 times) with PCR buffer (10mM Tris, $50 \mathrm{mM} \mathrm{K} \mathrm{Cl,} 3.5 \mathrm{mM} \mathrm{Mg} \mathrm{Cl} 2$ ) by centrifugation. A $20 \%$ of Chelex 100 (Bio-Rad Lab., Calif.) was mixed with fecal samples $(20 \mu \mathrm{l}$ of chelx stock to $100 \mu \mathrm{l}$ of samples). Then, samples were subjected to six cycles of freezing and thawing to release the DNA from oocysts using dry ice-ethanol bath for freezing and water bath $\left(98{ }^{\circ} \mathrm{C}\right)$ for thawing with incubation time from 1 to 2 minutes in each bath. Lastly, samples were centrifuged and $50 \mu 1$ of supernatant was used as the template in the PCR assay.

\section{DNA amplification}


The primer set described by Laberge et al. (1996) was used in PCR which specific for Cryptosporiudium parvum. Sequences of primers were as follows: forward -5 GCC CAC CTG GAT ATA CAC TTT C3"; reverse - 5 TCC CCC TCT CTA GTA CCA ACA GGA 3'. The size of the amplified product was $358 \mathrm{bp}$. The PCR mixture contained PCR reaction buffer (10 mM Tris- $\mathrm{HCl}, 1.5 \mathrm{mM} \mathrm{MgCl}, 50 \mathrm{mM} \mathrm{KCl}, \mathrm{pH} 8.3)$ and contained $1.0 \mathrm{mM}$ each of forward and reverse primers, $0.2 \mathrm{mM}$ each dATP, dGTP, dCTP and dTTP, $100 \mathrm{mg} / \mathrm{ml} \mathrm{BSA}$ and $2.5 \mathrm{U}$ Taq DNA polymerase (Boehringer Mannheim Canada, Laval, Que'bec, Canada). 10 $\mu 1$ of template DNA was added in the case of fecal samples and $30 \mu \mathrm{l}$ in the case of filtered environmental water pellet suspensions. Reaction mixtures were initially denaturated at $94{ }^{\circ} \mathrm{C}$ for $1 \mathrm{~min}$, and then subjected to 40 cycles of denaturation at $94{ }^{\circ} \mathrm{C}$ for $15 \mathrm{~s}$, annealing at $50^{\circ} \mathrm{C}$ for $1 \mathrm{~min}$ and extension at $72{ }^{\circ} \mathrm{C}$ for $1 \mathrm{~min}$, with an additional 7 -min extension at $72{ }^{\circ} \mathrm{C}$.

\section{Detection of PCR products}

The amplification products were identified by running $20 \mu \mathrm{l}$ of the PCR reaction mixture in $2 \%$ agrose gel in Tris acid EDATA buffer. Gel was run at $100 \mathrm{~V}$ for 1 Hour, stained with ethodium bromide solution for 30 minutes and PCR product bands visualized under UV light. The expected PCR product is $358 \mathrm{bp}$.

\section{RESULTS}

Table 1: Incidence of Cryptosporidium parvum oocysts from different collected water samples.

\begin{tabular}{|l|c|c|c|}
\hline \multicolumn{1}{|c|}{ Types of samples } & $\begin{array}{c}\text { Surface water } \\
\text { samples }\end{array}$ & Dug-well water & Tap-water \\
\hline Samples number & 10 & 12 & 12 \\
\hline Positive samples & 7 & 7 & 5 \\
\hline $\begin{array}{l}\text { Percentage of } \\
\text { positive samples }\end{array}$ & $70 \%$ & $58.33 \%$ & $41,66 \%$ \\
\hline Overall percentage & \multicolumn{3}{|l}{$55.88 \%$} \\
\hline
\end{tabular}

Table 2: Incidence of Cryptosporidium parvum oocysts from fecal specimens of buffaloes and sheep.

\begin{tabular}{|l|c|c|c|c|}
\hline Types of samples & $\begin{array}{c}\text { Adult } \\
\text { buffaloes }\end{array}$ & $\begin{array}{c}\text { Buffaloe`s } \\
\text { calf }\end{array}$ & Adult ewes & Lambs \\
\hline Samples number & 15 & 14 & 15 & 30 \\
\hline Positive samples & 7 & 8 & 6 & 17 \\
\hline $\begin{array}{l}\text { Percentage of positive } \\
\text { samples }\end{array}$ & $46.66 \%$ & $57.14 \%$ & $40.00 \%$ & $56.66 \%$ \\
\hline Overall percentage & \multicolumn{2}{|c|}{$51.77 \%$} & \multicolumn{2}{c|}{$51.11 \%$} \\
\hline
\end{tabular}




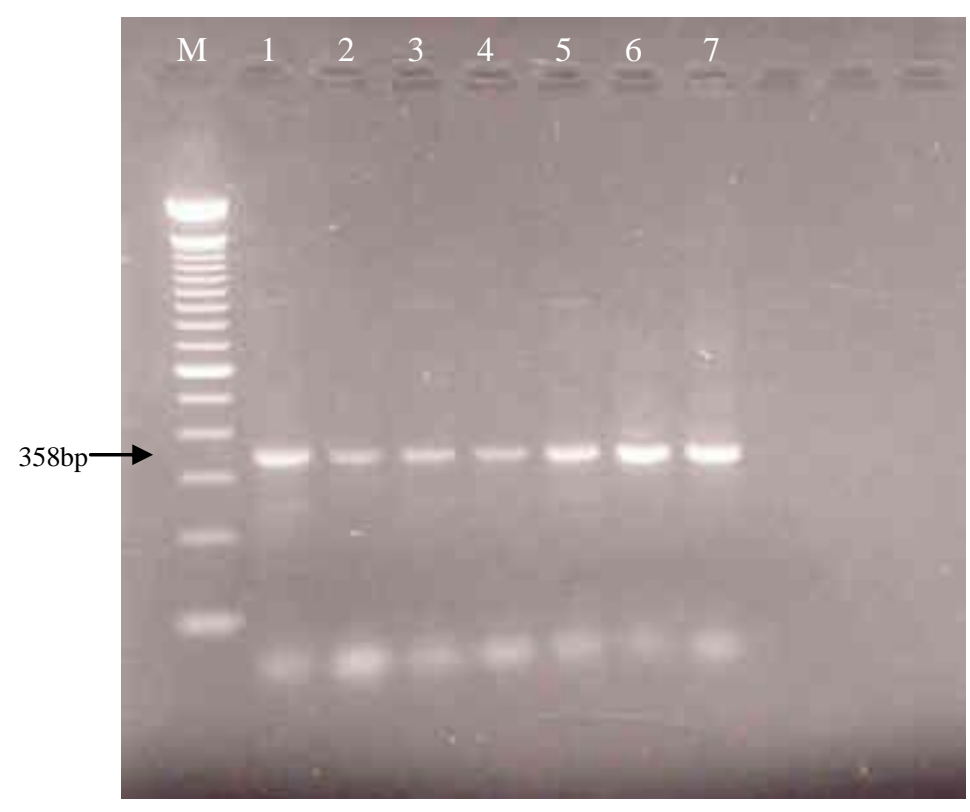

Figure 1: Sensitivity of the PCR assay for detection of Cryptosporiudium parvum as determined by $2 \%$ agarose gel electrophoresis. M: $100 \mathrm{bp}$ ladder, Lane 1: positive lambs, Lane 2: positive ewes, Lane 3: positive buffaloe calves, Lane 4: positive adult water-buffaloes, Lane 5: tap-water, Lane 6: dug-well water, Lane 7: positive surface water.

\section{DISCUSSION}

Cryptosporidium parvum is an opportunistic protozoan that is ubiquitous in its geographic distribution and range of vertebrate hosts. C. parvum causes diarrheal disease in human and several animal species known as Cryptosporidiosis (Johnson et al., 1995). Transmission of the parasite is via oral ingestion of contaminated waters or food with the infective oocyst. Environmental Cryptosporidium contamination, especially contamination of drinking water, has not been much attention in Assiut.

Oocysts of Cryptosporidium parvum were detected in water samples and fecal specimens of buffaloes and sheep. The frequency of Cryptosporidium parvum oocysts appearance in water samples is shown in Table 1, a total of 34 water samples were examined using PCR for Cryptosporidium parvum, 19 of the them $(55.88 \%)$ were positive overall, ranging from a high of $70 \%$ positive for local water stream, followed by 
$58.33 \%$ and $41.66 \%$ positive for dug-well and drinking tap water samples, respectively.

Our data indicate a relatively overall higher contamination rate of water with Cryptosporidium oocysts other than that of Johnson et al. (1995) who found that overall positive samples was 31.9\%, ranging from a high of $54.2 \%$ positive for waste water to a low of $8.7 \%$ positive for costal waters. The data in Table (1) clear out that the incidence rate of Cryptosporidium parvum oocysts in drinking water either tap-water or dugwell water is higher than that recorded by Johnson et al. (1995) (16.7) and Rose et al. (1991) (17\%). The variation in these results may be due to the difference of the sources that polluted the water and the extend of spread of that disease at the locality.

On contrary, our results of local water surface were lowered than that detected by LeChevallier et al. (1991) (87\%), Rose, 1997 (77\%), Ongerth and Stibbs (1987) and Hashimoto et al. (2002) who detect the oocysts of Cryptosporidium in all examined river water samples.

Table 2, illustrated that the overall percentage of Cryptosporidium parvum among buffaloes and sheep in Assiut province, Egypt were 51.77\% and $51.11 \%$, respectively. Moreover, the table showed that the percentage of Cryptosporidium parvum oocysts in adult female buffaloes and buffaloe's calves were $46.66 \%$ \& $57.14 \%$, respectively and ewes and lambs were $40.00 \%$ \& $56.66 \%$, respectively. Our result was more or less coincided with Chalmers et al. (2002) who could detect Cryptosporidium oocysts from fecal samples of two- sheep flocks in the following percentage, $57 \%$ and $47 \%$, from flock $\mathrm{A}$ and B, respectively, Chalmers et al. (1994) detected Cryptosporidium spp. in the faeces of unweaned lambs was 9\% and in ewes 6\% while Angus et al. (1982) detected 29/37 (78.37\%) Cryptosporidium spp. in a flock of diarrhoeic lamb.

From the above mentioned data, we stated that the source of oocysts in outbreaks among buffaloes and sheep associated with surface and drinking water in the Assiut has been attributed to contamination by both animal faeces and human sewage (Anonymous, 1998) as local farmers graze their animals (water buffaloes and sheep) near the shore of surface water streams. The local residents use area near irrigated channels as open toilets and many housewives used it for disposal of waste-water and food refuse. Also, the high frequency of Cryptosporidium in drinking water may be attributed to a connection of water source with human wastes as well as Cryptosporidium is unaffected by many current water treatment techniques such as chlorination and, as there is no effective treatment for cryptosporidiosis (Korich et al., 1990; Johnson et al., 1995). 
In conclusion, we would like to emphasize the need for continued development of rapid, sensitive and effective methods for monitoring the occurrence of Cryptosporidium oocysts in surface and municipal water. Good management and agricultural practices designed to minimize animal Cryptosporidiosis, however, can also minimize surface water contamination such as restriction the access of animals to surface water e.g via use of electric wire. Additional management practices that can decrease water contamination include containment of manure by creation of lagoons for manure decomposing or disinfection of raw manure accumulated near water. The conventional bacteriological indicators of microbial indicators of microbial water quality do not necessarily correlate with the presence of concentrations of cryptosporidium. Therefore, accurate identification of its modes of transmission is of critical importance in evaluating water treatment procedures and the public health risk from cryptosporidiosis.

\section{Acknowledgements}

This research was supported by National Agricultural Research Centre for Kyushu Okinawa Region, Kumamoto, Japan, Department of Animal Hygiene and Department of Animal Medicine, Faculty of Veterinary Medicine, Assiut University, Assiut, Egypt

\section{REFERENCES}

Angus, K.W. (1990): Cryptosporidium in ruminants. In Dubey, J.P., Speer, C.A., Fayer, R. (Eds.). Cryptosporidiosis in man and animals, CRC Press, Boca Raton, FL, pp. 83-103.

Angus, K.W.; Appleyard, W.T.; Menzies, J.D.; Campbell, I. and Sherwood,

D. (1982): An outbreak of diarrhea associated with Cryptosporidiosis in naturally reared lambs. Vet. Rec., 110: 129-130.

Aldom, J.E. and Chagla, A.H. (1995): Recovery of Cryptosporidium oocysts from water by a membrane filter dissolution methods. Lett. Appl. Microbiol. 20: 186-187.

Anonymous, (1998): Cryptosporidium in water supplies: third reports of the group of the Group of Experts to: Department of the environment, Transport and the Regions \& Department of health. DETR, London.

Casemore, D.P.; Wright, S.E. and Coop, R.L. (1997): CryptosporidiosisHuman and Animal Epidemiology. In "Cryptosporidium and Cryptosporidiosis" (R.Fayer, Ed.), pp.65-92. CRC Press, Boca Raton, FL. 
Chalmers, R.M.; Elwin, K.; Reilly, W.J.; Irvine, H.; Thomas, A.L. and Hunter, P.R. (2002): Cryptosporidium in farmed animals: the detection of a novel isolate in sheep. International journal for Parasitology, 32: 21-26.

Chalmers, R.M.; Sturdee, A.P.; Casemore, D.P.; Curry, A.; Miller, A. and Richmond, T. (1994): Cryptosporidium muris in wild house mice: first report in the UK. Eur. J. Parasitology, 30: 151-155.

de-Graaf, D.C.; Vanopdenbosch, E.; Ortega-More, L.M.; Abbassi, H. and Peters, J.E. (1999): A review of the importance of cryptosporidiosis in farm animals. Int. J. Parasitol. 29: 1269.

Johnson, D.W.; Pieniazek, N.J.; Griffin, D.W.; Misener, L. and Rose, J.B. (1995): Development of a PCR protocol for sensitive detection of Cryptosporidium oocysts in water samples. Applied and Environmental Microbiology, November, p. 3849-3855.

Graczyk, T.K.; Faayer, R. and Granfield, M.R. (1997a): Zoonotic transmission of Cryptosporidium from water samples by the membrane -filter dissolution methods. Parasitology research.83: 121-125.

Hashimoto, A.; Kunikane, S. and Hirata, T. (2002): Prevalance of Cryptosporidium oocysts and Giardia cysts in the drinking water supply in Japan. Water research 36: 519-526.

Kauncer, C. and Stinear, T. (1998): Sensitive and rapid detection of viable Giardia cysts and Cryptosporidium parvum oocysts in large volum water samples with wound fiberglass cartridge filter and reverse transcription- PCR. App Environm Microbiol., 64(5): 1743-1749.

Korich, D.G.; Mead, J.R.; Madore, M.S.; Sinclair, N.A. and Sterling, C.R. (1990): Effects of ozone, chlorine dioxide, chlorine, and monochloramine on Cryptosporidium parvum oocyst viability. Appl. Environ. Microbiol. 1990 May, 56(5): 1423-8.

Kostraznska, M.; Sankey, M.; Haack, E.; Power, C.; Aldom, J.E.; Chagla, A.H.; Unger, S.; Palmateer, H.; Trevors, J.T. and De Grandis, S.A. (1999): Three sample preparation protocols for polymerase chain reaction based detection of Cryptosporidium parvum in environmental samples. J. Microbiological Methods 35: 65-71.

Laberge, I.; Ibrahim, A.; Barta, J.R. and Griffiths, M.W. (1996): Detection of Cryptosporidium parvum in raw milk by PCR and oligonucleotide hybridization. Appl. Environ. Microbiol. 62: 3259-3264. 
LeChevallier, M.W.; Norton, W.D. and LEE, R.G. (1991): Occurrence of Giardia and Cry ptosporidium spp. in Surface Water Supplies: Appl. Environ. Microbiol, Sept., p. 2610-2616.

LeChevallier, M.W.; Di Giovanni, GD.; Clancy, J.L.; Bukhari, S. and Rosen, J.S. (2003): Comparison of methods of cell culture PCR for detection of Cryptosporidium spp in source waters. Appl. Env. Microbiol., 69: 971-979.

Lowery, C.J.; Moore, J.E.; Millar, B.C.; Burke, D.B.; MacCorry, K.A.J.; Crothers, E. and Dooley, S.G. (2000): Detection and speciation of cryptosporidium spp. In environmental water samples by immunogentic separation, PCR and endeonuclease restriction. J.Med. Microbiology, Vol.49: 779-785.

Olson, M.E.; O'Handley, R.M.; Ralston, B.J.; McAllister, T.A. and Thompson, R.C.A. (2004): Update on Cryptosporidium and giardia infections in cattle. Trends Parasitol. 20: 185.

Ongerth, J.E. and Stibbs, H.H. (1987): Identification of Cryptosporidium oocysts in river water. Appl. Environ. Microbiol.53: 672-676

Rose, J.B. (1997): Occurrence and significance of Cryptosporidium in water. J. Am. Water Works Assoc. 80: 53-58.

Rose, J.B.; Gerba, C.P. and and Jakubowski, W. (1991): Survey of potable water supplies for cryptopodium and Giardia. Environ. Sci. Technol., 1991, 25 (8), pp 1393-1400.

Rose, J.B.; Lisle, J.T. and LeChevallier, M. (1997): Waterborne cryptosporidiosis: Incidence, outbreaks and treatment stratigies. In: Cryptosporidium and Cryptosporidiosis, "R. Fayer, Ed." Pp.93-110 CRC Press, Boca Raton, FL. Ibrahim, J 